НАУКОВИЙ ВІСНИК

Scientific messenger of Lviv National University of
Veterinary Medicie and Biotechnolonies

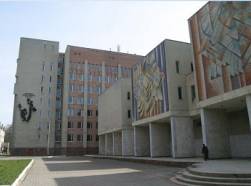

Том 22 № 100

2020
Науковий вісник Дьвівського національного університету ветеринарної медицини та біотехнологій імені С.3. Гжицького. Серія: Ветеринарні науки

Scientific Messenger of Lviv National University of Veterinary Medicine and Biotechnologies. Series: Veterinary sciences

UDC 636.2:591.463.1.

\title{
Connection between the fertilizing capacity of spermatozoa and the content of lipoproteins in bull sperm
}

\author{
V. Ju. Stefanyk ${ }^{1}$, S. J. Kava ${ }^{1}$, D. D. Ostapiv ${ }^{2}$, I. M. Jaremchuk ${ }^{2}$ \\ ${ }^{1}$ Stepan Gzhytskyi National University of Veterinary Medicine and Biotechnologies Lviv, Ukraine \\ ${ }^{2}$ Institute of Animal Biology of NAAS, Lviv, Ukraine
}

\section{Article info}

Received 12.10.2020

Received in revised form 11.11.2020

Accepted 12.11.2020

Stepan Gzhytskyi National University of Veterinary Medicine and Biotechnologies Lviv, Pekarska Str., 50, Lviv, 79010, Ukraine.

Tel.: +38-097-553-09-20

E-mail:kava.sv@gmail.com

Institute of Animal Biology, V. Stus Str. 38, Lviv, 79034, Ukraine.
Stefanyk V. Ju., Kava S. J., Ostapiv, D. D., \& Jaremchuk, I. M. (2020). Connection between the fertilizing capacity of spermatozoa and the content of lipoproteins in bull sperm. Scientific Messenger of Lviv National University of Veterinary Medicine and Biotechnologies. Series: Veterinary sciences, 22(100), 84-87. doi: 10.32718/nvlvet10015

The relationship between the activity of enzymes-markers of fertility of succinate dehydrogenase and cytochrome oxidase with the content of lipoproteins in bull ejaculates was studied. The research was conducted at the Stepan Gzhytskyi National University of Veterinary Medicine and Biotechnologies Lviv and the Lviv National Production Center "Zakhidplemresursy". Physiological indicators of the quality of bull ejaculates (volume, $\mathrm{ml}$; sperm motility, scores; concentration, $10^{9}$ cells $/ \mathrm{ml}$ ) and the activity of enzymesmarkers of reproductive capacity of germ cells were studied. Freshly obtained bull ejaculates are characterized by a volume of $4.3 \pm 0.18 \mathrm{ml}$, a concentration of $1.09 \times 10^{9}$ cells $/ \mathrm{ml}$ and sperm activity of $7.4 \pm 0.16$ points. The activity of enzymes-markers of fertilization ability of germ cells shows a positive relationship with the content of very high density lipoproteins. In particular, for less than 30.0 units $/ \mathrm{h} \times$ $0.1 \mathrm{ml}$ of semen enzyme activity revealed a minimum content of the fraction (22.1-23.4\%), which increases by $5.0-9.9 \%$ with an increase to 50.0 units $/ \mathrm{h} \times 0.1 \mathrm{ml}$ of semen and increases by another $14.6-25.4 \%$ by more than 50.0 units $/ \mathrm{h} \times 0.1 \mathrm{ml}$ of semen. Bull semen contains the main fractions of lipoproteins: chylomicrons $(26.5 \pm 2.20 \%$ ), very low density $-10.4 \pm 0.44 \%$, low $-18.3 \pm 1.84 \%$, high $-17.1 \pm 1.09 \%$ and very high density $-26.8 \pm 1.94 \%$, and sperm show $24.7 \pm 2.79$ units $/ \mathrm{h} \times 0.1 \mathrm{ml}$ of sperm succinate dehydrogenase and $36.7 \pm 2.66$ units $/ \mathrm{h} \times 0.1 \mathrm{ml}$ of sperm cytochrome oxidase. With a proportional increase in the activity of succinate dehydrogenase, the content of low and high density lipoproteins in semen shows a negative correlation $(\eta=0.202-0.295)$ and with a very high density - positive $(\eta=0.490)$, and cytochrome oxidase with a high content of chylomitecron and negative chylomicron and lipoproin $=0.352$ and 0.438 ) and from a very high density - positive $(\eta=0.674)$. With a proportional increase in the activity of enzymes-markers of the fertilizing ability of germ cells, the content of chylomicrons, low and high density lipoproteins decreases, and the content of very high density lipoproteins increases.

Key words: dogs, teeth, clinical, dental research, dental indices, immune status tartar, oral fluid, septogel, argumentistin.

\section{Зв'язок активності ензимів-маркерів запліднювальної здатності статевих клітин 3 вмістом ліпопротеїнів сперми бугаїв}

\author{
В. Ю. Стефаник ${ }^{1}$, С. Й. Кава ${ }^{1}$, Д. Д. Остапів ${ }^{2}$, І. М. Яремчук ${ }^{2}$
}

${ }^{1}$ Львівський національний університет ветеринарної медицини та біотехнологій імені С. 3. Госииького, м. Львів, Украӥна

${ }^{2}$ Інститут біологї̈ тварин НААН, м. Львів, Україна

Вивчали зв'язки активності ензимів-маркерів запліднювальної здатності сукиинатдегідрогенази та иитохромоксидази з вмістом ліпопротеїнів в еякулятах бугаӥв. Дослідження проведені в Львівському національному університеті ветеринарної медицини 
та біотехнологій імені С. 3. Гжицького та Львівському національно-виробничому иеетрі “Західплемресурси”. Досліджували фізіологічні показники якості еякулятів бугаӥв (об 'єм, мл; рухливість спермїв, бали; концентрацію, $10^{9}$ клітин/мл) та активність ензимів-маркерів запліднювальної здатності статевих клітин. Свіжоотримані еякуляти бугаӥв характеризуються об'ємом -

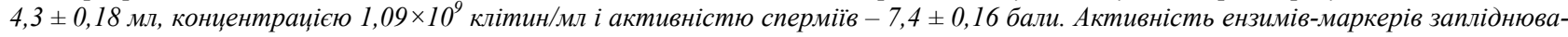
льної здатності статевих клітин проявляє позитивний зв'язок з вмістом ліпопротеїнів дуже високої щільності. Зокрема, за менше 30,0 од/год ×0,1 мл сперми активності ензимів виявлено мінімальний вміст фракиї (22,1-23,4\%), який зростає на 5,0-9,9 \% за збільшення до 50,0 од/год×0,1 мл сперми і ще на 14,6-25,4\% підвищується за більше 50,0 од/год×0,1 мл сперми. Сперма бугаӥв містить основні фракції ліпопротеїнів: хіломікрони $(26,5 \pm 2,20 \%)$, дуже низької щільності - 10,4 \pm 0,44 \%, низької - 18,3 \pm

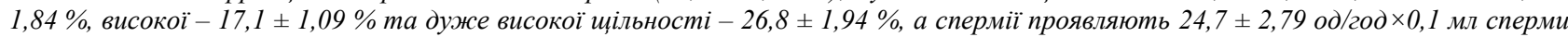
сукцинатдегідрогенази і 36,7 \pm 2,66 од/год ×0,1 мл сперми цитохромоксидази. При пропориійному підвищенні активності сукцинатдегідрогенази вміст ліпопротеїнів низької та високої шільності у спермі проявляє кореляцію негативну ( $\eta=0,202-0,295)$ $і$ з дуже високої щиільності - позитивну $(\eta=0,490)$, а цитохромоксидаза з вмістом хіломікрон та ліпопротеїнів дуже низької шільності-негативну $(\eta=0,352$ та 0,438) $і$ з дуже високої шільності- позитивну $(\eta=0,674)$. За пропориійного підвищення активності ензимів-маркерів запліднювальної здатності статевих клітин знижується вміст хіломікрон, низької та високої шільності ліпопротеїнів і підвищується - ліпопротеїнів дуже високої щуільності.

Ключові слова: активність, сукцинатдегідрогеназа, ичитохромоксидаза, ліпопротеїни, сперма, бугай.

\section{Вступ}

Спермії, після еякуляції, інтенсивно використовують субстрати плазми сперми і проявляють поступальний рух. Доведено, що енергію для руху спермії бугаїв отримуюють шляхом використання присутніх в плазмі сперми вуглеводів, ліпідів та протеїнів, а одним з основних біохімічних процесів, за рахунок якого ресинтезується АТФ, є дихання (Shergin, 1967; Iablonskyi et al., 2009; Yaremchuk et al., 2017). При цьому виявлено, що наявність і швидкість перетворення та використання субстратів й транспорт електронів у ланках дихального ланцюга мітохондрій статевих клітин характеризує якість і запліднювальну здатність сперміїв (Kosenko et al., 2007; Salina \& Gorbunov, 2015). Зокрема, активність ФАД-залежної (сукцинатдегідрогенази; СДГ) і кінцевої (цитохромоксидази; ЦХО) ланок дихального ланцюга мітохондрій позитивно корелює 3 характеристиками еякулятів (концентрацією і кількістю живих сперміїв) та фізіологічними показниками якості статевих клітин (виживанням і резистентністю) і запліднювальною здатністю (Zvereva et al., 1989; Hrymak, 2020).

Оскільки спермії для руху здатні окиснювати і використовувати ліпіди, як джерело енергії для ресинтезу АТФ, вивчали зв'язок між активністю ензимівмаркерів запліднювальної здатності статевих клітин та вмістом ліпопротеїнів сперми бугаїв.

\section{Матеріал і методи досліджень}

Дослідження проведені в Львівському національному університеті ветеринарної медицини та біотехнологій імені С. 3. Гжицького та Львівському національно-виробничому центрі “Західплемресурси”. Досліджували фізіологічні показники якості еякулятів бугаїв (об'єм, мл; рухливість сперміїв, бали; концентрацію, $10^{9}$ клітин/мл) та активність ензимів-маркерів запліднювальної здатності статевих клітин. Активність цитохромоксидази (ЦХО; цитохром С : $\mathrm{O}_{2}-$ оксидоредуктаза, КФ. 1.9.3.1.) визначали з викорис- танням 3 реактиву “наді”, а сукцинатдегідрогенази (СДГ; сукцинат: (акцептор) - оксидоредуктаза, КФ. 1.3.99.1) 3 2,3,5-трифенілтетразолієм і натрій сукцинатом (од/год×0,1 мл сперми; C) (Chukhrii \& Klevets, 1978). Вміст окремих фракцій ліпопротеїнів досліджували електрофорезом в поліакриламідному гелі 3 градієнтом концентрацій акриламіду: 3,5 \%, $5,0 \%$ та 7,5\%. Зразки сперми перед проведенням електрофорезу фарбували (до 0,1 мл свіжоотриманої сперми додавали 0,03 мл 0,1 \% розчин фарб Судан III + Судан IV (1 : 1) у 70 \% етиловому спирті), інкубували у темноті 30 хв та вносили 0,07 мл зразка у лунки концентруючого гелю. Після електрофорезу виявляли 5 основних фракцій, які ідентифікували відносно зон рухливості ліпопротеїнів сироватки крові: хіломікрони (ХМ), ліпопротеїни дуже низької щільності ЛП (ДНЩ), низької (НЩ), високої (ВЩ) і дуже високої щільності (ДВЩ). Вміст ліпопротеїнів (\%) визначали 3 використанням програмного забезпечення TotalLab TL120. Результати досліджень опрацьовано статистично (Plohinskij, 1969).

\section{Результати та їх обговорення}

Еякуляти бугаїв характеризуються: об'ємом $4,3 \pm 0,18$ мл, концентрацією спермів $-1,09 \times 10^{9}$ клітин/мл і активністю 7,4 $\pm 0,16$ бали. У спермі активність ензимів-маркерів становить: СДГ - 24,7 \pm 2,79 од/ год×0,1 мл сперми, а ЦХО - 36,7 $\pm 2,66$ од/год×0,1 мл сперми. При цьому, вміст фракцій ліпопротеїнів (відповідно до протеїнів сироватки крові): хіломікрон (ХМ) $26,9 \pm 1,93$ \% та ліпопротеїни (ЛП): дуже низької щільності (ДНЩ) - 10,4 \pm 0,44 \%, низької (НЩ) - 18,3 \pm $1,84 \%$, високої (ВЩ) - 17,1 $\pm 1,09 \%$ та дуже високої щільності (ДВЩ) $-26,8 \pm 1,94 \%$.

Аналіз кореляцій між активністю ензимів та ліпопротеїнами сперми свідчить, що до 50,0 од/год×0,1 мл сперми СДГ вмістом хіломікрон однакова $(26,7 \%)$ i знижується на 6,4 \% за більше 50 од/год×0,1 мл сперми (табл.). 


\section{Таблиця}

Зв'язок між активністю ензимів-маркерів запліднювальної здатності статевих клітин та вмістом ліпопротеїнів сперми бугаїв

\begin{tabular}{|c|c|c|c|c|c|c|c|}
\hline \multirow{3}{*}{$\begin{array}{c}\text { Фракції ліпопротеїнів (ЛП), } \\
\text { \% }\end{array}$} & \multicolumn{6}{|c|}{ Сукцинатдегідрогеназа, од/год×0,1 мл сперми } & \multirow{3}{*}{$\eta$} \\
\hline & \multicolumn{2}{|r|}{$30,0<$} & \multicolumn{2}{|c|}{$30,0-50,0$} & \multicolumn{2}{|c|}{$>50,0$} & \\
\hline & $\mathrm{n}$ & $\mathrm{M} \pm \mathrm{m}$ & $\mathrm{n}$ & $\mathrm{M} \pm \mathrm{m}$ & $\mathrm{n}$ & $\mathrm{M} \pm \mathrm{m}$ & \\
\hline $\mathrm{XM}$ & 39 & $26,4 \pm 2,77$ & 3 & $26,7 \pm 5,80$ & 7 & $20,3 \pm 2,41$ & 0,076 \\
\hline пре- $\beta$ ЛП (ДНЩ) & 39 & $7,7 \pm 0,63$ & 3 & $8,0 \pm 0,94$ & 6 & $6,0 \pm 1,36$ & 0,174 \\
\hline 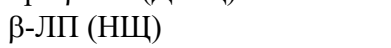 & 39 & $23,3 \pm 2,48^{*}$ & 3 & $17,1 \pm 1,58$ & 7 & $13,6 \pm 3,95$ & 0,202 \\
\hline$\alpha-Л \Pi$ (ВЩ) & 37 & $19,1 \pm 1,36^{*}$ & 3 & $16,3 \pm 1,52$ & 6 & $10,3 \pm 3,60$ & 0,295 \\
\hline \multirow[t]{3}{*}{ ДВЩ } & 30 & $23,4 \pm 1,54$ & 3 & $33,3 \pm 5,58$ & 6 & $38,0 \pm 5,93^{*}$ & 0,490 \\
\hline & \multicolumn{6}{|c|}{ Цитохромоксидаза, од/год×0,1 мл сперми } & \\
\hline & & $30,0<$ & & $0-50,0$ & & $>50,0$ & \\
\hline $\mathrm{XM}$ & 24 & $24,3 \pm 3,80^{* * *}$ & 17 & $21,1 \pm 3,91^{* *}$ & 7 & $9,6 \pm 1,86$ & 0,352 \\
\hline пре- $\beta$ ЛП (ДНЩ) & 24 & $6,9 \pm 0,78^{* *}$ & 16 & $8,5 \pm 0,91^{* * *}$ & 7 & $3,5 \pm 0,54$ & 0,438 \\
\hline 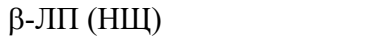 & 24 & $21,3 \pm 2,21$ & 17 & $23,6 \pm 4,82$ & 7 & $19,6 \pm 5,93$ & 0,148 \\
\hline$\alpha$-ЛП (ВЩ) & 22 & $21,8 \pm 2,02$ & 16 & $19,9 \pm 2,03$ & 6 & $18,2 \pm 2,81$ & 0,039 \\
\hline ДВШ & 17 & $22,1 \pm 2,31$ & 15 & $27,1 \pm 2,72$ & 4 & $47,5 \pm 9,10^{* *}$ & 0,674 \\
\hline
\end{tabular}

Примітка: різниця статистично вірогідна порівняно 3 мінімальною величиною значення: ** $-\mathrm{P}<0,01 ; * * *-\mathrm{P}<0,001$

Аналогічно, за менше 30,0 од/год×0,1 мл сперми ЦХО вміст хіломікрон високий $(24,3 \pm 3,80 \%)$, на $3,2 \%$ нижчий за 30,0-50,0 од/год $\times 0,1$ мл сперми і ще на $11,5 \%(\mathrm{P}<0,01)$ нижчий за більше 50,0 од/год $\times 0,1$ мл сперми.

За активністю СДГ і ЦХО для вмісту хіломікрон сила кореляції, відповідно, слабка $(\eta=0,076)$ і середньої сили $(\eta=0,352)$ негативна.

Відомо, що хіломікрони є екзогенні ліпопротеїни головною функцією яких є транспорт ліпідів. Ймовірно, ліпідна частина XМ (можливо й протеїнова) як енергетичний матеріал, використовується у мітохондріях сперміїв для ресинтезу АТФ. СДГ меншою мірою, порівняно з ЦХО, характеризує використання ХМ сперміями.

Не виявлено зв'язку СДГ з вмістом ліпопротеїнів дуже низької щільності, величина значення яких знаходилась в межах 6,0-8,0 \% при зміні активності ензиму від менше 30,0 до більше 50,0 од/год $\times 0,1$ мл сперми. Однак, вміст ліпопротеїнів дуже низької щільності залежить від активності ЦХО: за менше 30,0 од/год $\times 0,1$ мл сперми величина значення $6,9 \pm 0,78 \%$, за підвищення до 50,0 од/год $\times 0,1$ мл сперми зростає на $1,6 \%$, а за більше 50,0 од/год× 0,1 мл сперми на 5,0 \% (P < 0,001) знижується. Кореляційне відношення для ліпопротеїнів дуже низької щільності за активністю СДГ слабке $(\eta=0,174)$, а за ЦХО середньої сили $(\eta=0,438)$.

Ліпопротеїни дуже низької щільності синтезуються в організмі (в тому числі й у додаткових статевих залозах) і за своїм складом, окрім ліпідної і протеїнової частин, містять невелику кількість вуглеводів (галактози, манози, фруктози, глюкозаміна та сіалових кислот). Тому ЛПДНЩ, аналогічно хіломікронам, $\epsilon$ джерелом субстратів для окиснення в мітохондріях сперміїв і ресинтезу АТФ для поступального руху.

Вміст ліпопротеїнів низької щільності високий $(23,3 \pm 2,48 \%)$ за менше 30 од/год×0,1 мл сперми СДГ, знижується на $5,2 \%$ за підвищення до 50 од/год×0,1 мл сперми і ще на 9,7 \% (Р< $<0,05$; $13,6 \pm 3,95 \%$ менший за більше 50 од/год $\times 0,1$ мл сперми. За менше 30,0 та більше 50,0 од/год×0,1 мл сперми ЦХО вміст вказаної фракції ліпопротеїнів $19,6-21,3 \%$, а за 30,0-50,0 од/год $\times 0,1$ мл сперми на 2,3-4,0 \% вищий. За активністю СДГ і ЦХО сила кореляції для вмісту ліпопротеїнів низької щільності слабка $(\eta=0,148-0,202)$.

Аналізом кореляції між активністю ензимів та Вміст ліпопротеїнів високої щільності високий $(19,1 \pm$ 1,36\%) за менше 30 од/год×0,1 мл сперми СДГ, на $2,8 \%$ знижується за підвищення до 50 од/год $\times 0,1$ мл сперми і ще на 6,0 \% менший за більше 50 од/год× 0,1 мл сперми. Різниця між максимальною і мінімальною величинами вмісту ЛПВЩ статистично вірогідна $(\mathrm{P}<0,05)$. Вміст ліпопротеїнів високої щільності $21,8 \pm 2,02 \%$ встановлено за менше 30,0 од/год× 0,1 мл сперми ЦХО, на 1,9 \% знижується за підвищення до 50,0 од/год $\times 0,1$ мл сперми і за більше 50,0 од/год $\times 0,1$ мл сперми становить $18,2 \pm 2,81 \%$, що на 3,6 \% нижче початкового значення. Ативність СДГ і ЦХО зі слабкою силою (відповідно, $\eta=0,295$ і 0,039) впливають на вміст ліпопротеїнів високої щільності.

Активність ензимів-маркерів запліднювальної здатності статевих клітин проявляе позитивний зв'язок 3 вмістом ліпопротеїнів дуже високої щільності. Зокрема, за менше 30,0 од/год $\times 0,1$ мл сперми активності ензимів виявлено мінімальний вміст фракції $(22,1-$ $23,4 \%$ ), який зростає на 5,0-9,9\% за збільшення до 50,0 од/год $\times 0,1$ мл сперми і ще на 14,6-25,4 \% підвищується за більше 50,0 од/год×0,1 мл сперми. Між мінімальним та максимальним вмістом ЛПДВЩ різниця статистично вірогідна ( $<<0,05-0,01)$. Сила кореляції між активністю ензимів і ліпопротеїнами дуже високої щільності середньої сили (СДГ - $=0,490$ i ЦХО $-\eta=0,674)$, позитивна.

Таким чином, активність ензимів-маркерів запліднювальної здатності статевих клітин характеризує ліпопротеїни, як джерело субстратів для окиснення в дихальному ланцюзі мітохондрій для забезпечення енергетичних потреб сперміїв. Спермії окиснюють ліпіди й інші мінорні компоненти у складі хіломікрон 
та ліпопротеїнів дуже низької щільності i, частково, високої щільності, що призводить до зменшення розміру молекули вказаних фракцій ліпопротїнів зі зростанням їх електрофоретичної рухливості - нагромадженням продуктів їх розщеплення, ліпопротеїнів дуже високої щільності.

\section{Висновки}

1. Свіжоотримані еякуляти бугаїв характеризуються: об'єм - 4,3 $\pm 0,18$ мл, концентрація $1,09 \pm 0,11 \times 10^{9}$ клітин/мл і активність сперміїв $-7,4 \pm$ 0,16 бали.

2. У свіжооториманих еякулятах бугаїв проявляється активність СДГ - 24,7 $\pm 2,79$ од/год×0,1 мл сперми і ЦХО - 36,7 $\pm 2,66$ од/год×0,1 мл сперми.

3. У спермі встановлені фракції ліпопротеїнів хіломікрони $(26,9 \pm 1,93 \%)$, ліпопротеїнів дуже низької щільності $(10,4 \pm 0,44 \%)$, низької $(18,3 \pm 1,84 \%)$, високої $(17,1 \pm 1,09 \%)$ та дуже високої щільності $(26,8 \pm 1,94 \%)$.

4. За пропорційного підвищення активності ензимів-маркерів запліднювальної здатності статевих клітин знижується вміст хіломікрон, низької та високої щільності ліпопротеїнів і підвищується - ліпопротеїнів дуже високої щільності.

\section{References}

Chukhrii, B. M., \& Klevets, L. O. (1978). Do metodyky vyznachennia aktyvnosti okysliuvalnykh fermentiv $u$ spermi buhaiv. Rozvedennia ta shtuchne osimeninnia velykoi rohatoi khudoby, 10, 42-45 (in Ukrainian).

Hrymak, K. (2020). Cryopreservation of ram-sires semen and its qualitative changes under the influence of low temperatures. Scientific Messenger of LNU of Veterinary Medicine and Biotechnologies. Series: Agricultural Sciences, 22(93), 102-112. doi: 10.32718/nvlvet-a9318.

Iablonskyi, V. A., Khomyn, S. P., Zaviriukha, V. I., \& Demchuk, M. V. (2009). Biotekhnolohichni i molekuliarno-henetychni osnovy vidtvorennia tvaryn. Lviv "Afisha" (in Ukrainian).

Kosenko, M. V., Chukhrii, B. M., Kotsiumbas, I. Ya, \& Klevets, L. O. (2007). Reproduktyvna funktsiia i androlohichna dyspanseryzatsiia buhaiv. Lviv (in Ukrainian).

Plohinskij, N. A. (1969). Rukovodstvo po biometrii dlja zootehnikov. M.: Kolos (in Russian).

Salina, A. S., \& Gorbunov, L. V. (2015). Determination of eventual temperature of cooling of sperms and embryos of animals to immersion in liquid nitrogen. Scientific Messenger of LNU of Veterinary Medicine and Biotechnologies. Series: Veterinary Sciences, 17(3), 102-107. URL: https://nvlvet.com.ua/index.php/ journal/article/view/527.

Shergin, N. P. (1967). Biohimija spermatozoidov sel'skohozjajstvennyh zhivotnyh. M.: Kolos (in Russian).

Yaremchuk, I., Kuzmina, N., Ostapiv, D., SharanM., \& Kava, S. (2017). Oxidative processes intensity and quallity of bull semen when adding microelements nanosuccinate compounds. Scientific Messenger of LNU of Veterinary Medicine and Biotechnologies. Series: Veterinary Sciences, 19(77), 185-189. doi: 10.15421/nvlvet7740.

Zvereva, G. V., Chuhrij, B. N., \& Klevec, L. A. (1989). Sukcinatdegidrogenaznaja aktivnost' spermy bykov i kachestvo spermiev. Sel'skohozjajstvennaja biologija, 6, 30-34 (in Russian). 